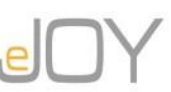

Kılıç, M. / Journal of Yasar University, 2019, 14/54, 127-140

\title{
Borsa İstanbul Şirketlerinin Kapsamlı Gelir Raporlama Uygulamaları Üzerine Bir Araştırma
}

A Research on the Comprehensive Income Reporting Applications of Borsa Istanbul Companies

Merve KILIÇ, Bağımsız Araştırmacı, Türkiye, merve.kilic@ outlook.com

Öz: Kapsamlı gelir, gittikçe önem kazanan bir performans ölçütü olmaktadır. Bu çalışmanın temel amacı, Borsa İstanbul (BİST)'da yer alan ișletmelerin 2009 ve 2017 yılları arasındaki kapsamlı gelir tablolarını içerik bakımından analiz etmektir. Ayrıca, bu çalıșma diğer kapsamlı gelir unsurlarının toplam kapsamlı gelir ve kârlılı oranları üzerindeki etkisini Wilcoxon işaretli sıralar toplamı ve işaret testini kullanarak incelemeyi de amaçlamaktadır. Calıșmanın bulgularına göre, kapsaml gelir unsurlarını raporlayan işletme sayısı 2009 ve 2017 yılları arasında önemli bir derecede artmıştır. Ayrıca, sonuçlar diğer kapsamlı gelir unsurlarının 2012 ve 2014 haricindeki yıllar için toplam kapsamlı gelir ve kârlılık oranları üzerinde istatistiki olarak anlamlı bir etkisinin olduğunu göstermiştir.

Anahtar Kelimeler: Diğer Kapsamlı Gelir Unsurları, Kapsamlı Gelir, Kârlılık Oranları, UMS 1

Abstract: Comprehensive income is becoming an increasingly important corporate performance indicator. The main purpose of this study is to analyze comprehensive income statements of the entities on Borsa Istanbul (BIST) with respect to their content throughout the years between 2009 and 2017. Further, this study also aims to investigate the impact of other comprehensive income items on the total comprehensive income and profitability ratios by employing Wilcoxon signed-rank test. According to the findings of the study, the number of the entities reporting other comprehensive income items has increased significantly between 2009 and 2017. Further, the results show that other comprehensive income items have a statistically significant impact on both the total comprehensive income and profitability ratios except for the years 2012 and 2014.

Keywords: Other Comprehensive Income Items, Comprehensive Income, Profitability Ratios, IAS 1

\section{Giriş}

Geleneksel görüş olarak da bilinen cari faaliyet performansı görüşünde finansal performans, geleneksel gelir tablosunda raporlanan kâr (zarar) yoluyla ölçülür (Ulusan, 2013: 46). Gerçekleşmiş gelirler bir muhasebe dönemi boyunca özkaynaklarda artışa neden olan işletmenin ortakları tarafından özkaynaklara doğrudan yapılan katkılar dışındaki nakit veya alacağa dönüşmüş tutarladır (Örten vd., 2015: 30). Gerçekleşmemiş gelirler ise özkaynaklarda artışa neden olan ancak henüz nakde dönüşmemiş işletmenin ortakları tarafından özkaynaklara doğrudan yapılan katkılar dışındaki tutarlardır (Bayri, 2010: 101). Diğer bir ifade ile gerçekleşmemiş gelirler varlıkların kullanılmasından ziyade elde tutulmasından kaynaklanan nakde dönüşmemiş gelirlerdir (Örten vd., 2015: 30). Muhasebe Sistemi Uygulama Genel Tebliğinde yer alan muhasebenin temel kavramlarından ihtiyatlılık kavramına göre işletmeler muhtemel giderleri ve zararları için hemen karşılık ayırmakta ancak muhtemel gelir ve kârları için gerçekleşmelerine kadar herhangi bir muhasebeleştirme işlemi yapmamaktadırlar (Çetinoğlu ve Tutkavul, 2013: 148). Gerçeğe uygun değer esası ile birlikte ihtiyatlılık ilkesinde yer alan bu sınırın genişlemesi, işletmelerin gerçekleşmemiş gelir ve kazançlarını da raporlamalarını gerektirmiştir (Köse ve Gürkan, 2014: 22). Gerçekleşmemiş gelir ve kazançların kâr tanımı içinde yer alması kapsamlı gelir kavramını ortaya çıkarmıştır (Köse ve Gürkan, 2014: 22).

Kapsamlı gelir, geleneksel gelir tablosunda yer alan kâra (zarara) ek olarak bu tabloda yer almayan ve varlık veya borçların cari değerlerinde ortaya çıkan değişikliklerden kaynaklanan gerçekleşmemiş gelir ve giderleri de içermektedir (Ulusan, 2013: 49). Geleneksel gelir tablosu tarafindan tanınmayan kapsamlı gelir unsurlarını içeren finansal tablo kapsamlı gelir tablosu olarak adlandırılmaktadır (Acar, 2013: 30). Kapsamlı gelir tablosu, UMS 1 Finansal Tabloların Sunuluşu standardında adı geçen finansal durum tablosu (bilanço), özkaynak değişim tablosu ve nakit akış tablosu ile birlikte genel amaçlı finansal tablolar arasında yer almaktadır.

Kapsamlı gelir tablosunun finansal tablo kullanıcılara sağladığı birçok avantaj söz konusudur. İlk olarak, gerçekleşmemiş kazanç ya da kayıpları da içeren kapsamlı gelir tablosu, işletmelerin finansal performansının bir bütün olarak değerlendirilmesinde hem yöneticilere hem de yatırımcılara fayda sağlamaktadır (Doğan ve Ertugay, 2010). Diğer kapsamlı gelir bilgisi, gelecekteki nakit akışlarının büyüklüğü ve zamanlaması tahmininde de finansal tablo kullanıcılara yardımcı olmaktadır (Köse ve Gürkan, 2014). Ayrıca, kapsamlı gelir bilgisi, yöneticilerin işletmelerin risk durumunu göz önünde bulundurarak daha doğru kararlar almalarına olanak sağlamaktadır (Çetinoğlu ve Tutkavul, 2013: 166). Kapsamlı gelir bilgisini raporlamanın faydalarını savunan görüşlerin yanı sıra bazı olumsuz yönlerini ileri süren görüşler de mevcuttur. Kapsamlı gelir raporlamaya olumsuz bakanlar, diğer kapsamlı gelirde yer alan unsurların değişken olduklarını ve işletmelerin temel gelirlerinin bir göstergesi olmadıklarını ileri sürmektedirler (Demir vd., 2013: 77). Ayrıca, diğer kapsamlı gelir unsurlarını oluşturan gerçekleşmemiş kazanç ve kayıpların yöneticilerin kontrol 
edemediği piyasa koşulları tarafından belirlendikleri ve dolayısıyla yönetimin performansını yansıtmadıkları belirtilmektedir (Chambers vd., 2007). Diğer kapsamlı gelir unsurları ve toplam kapsamlı gelirler ile ilgili tartışmalar devam etmektedir. Diğer kapsamlı gelir unsurlarının geleneksel gelir tablosunda yer alan dönem kârı (zararı) üzerinde nasıl bir etki oluşturacağı ve finansal tablo kullanıcılarını ne yönde etkileyeceği gündemde olan bir konudur.

$\mathrm{Bu}$ çalışmada, Borsa İstanbul (BIST)'da işlem gören işletmelerin kapsamlı gelir tabloları ve bu tablolarda sundukları bilgiler incelenmiştir. Bu amaçla, 2009 ile 2017 yılları arasında kalan süre boyunca BİST’te işlem gören ve kapsamlı gelir bilgisi mevcut olan 53 adet işletmenin verisi elde edilmiştir. Öncelikle, işletmelerin kapsamlı gelir bilgisini hangi formatta raporlamayı tercih ettikleri incelenmiştir. Daha sonra, işletmelerin diğer kapsamlı gelir unsurlarını raporlama düzeyleri belirlenmiştir. Ayrıca, işletmelerin gelir tablolarında yer alan dönem kârları ve toplam kapsamlı gelirleri arasında istatistiki olarak anlamlı bir fark olup olmadığ 1 tespit edilmiştir. Bunun yanı sıra, işletmelerin geleneksel dönem kârlarından türetilen özkaynak kârlılık oranları ile kapsamlı gelir bilgileri kullanılarak hesaplanan özkaynak kârlılık oranları arasındaki istatistiki farklar incelenmiştir. İstatistiki farkları analiz etmek için parametrik olmayan Wilcoxon işaretli sıralar toplamı ve işaret testi kullanılmıştır.

Ulusal literatürde kapsamlı gelir tablosu ve diğer kapsamlı gelir unsurlarını inceleyen çalışmaların birçoğu konuyu sadece teorik olarak ele almıştır. Diğer kapsamlı gelir unsurlarını ve toplam kapsamlı geliri ampirik olarak inceleyen ise az sayıda araştırma vardır (Sarığlu ve Türel, 2012; Çetinoğlu ve Tutkavul, 2013; Köse ve Gürkan, 2014). Çetinoğlu ve Tutkavul (2013) aracı kurumlarda diğer kapsamlı gelir unsurlarının sadece toplam kapsamlı gelir üzerinde oluşturduğu etkiyi istatistiki olarak incelemişlerdir. Ulusal literatürde diğer kapsamlı gelir unsurlarının toplam kapsamlı gelir ve kârlılık oranları üzerinde oluşturduğu etkiyi istatistiki olarak inceleyen başka bir çalışmaya rastlanmamıştır. İşletmelerin diğer kapsamlı gelir unsurlarının ampirik olarak incelenmesi literatüre katkı sağlayacaktır. Diğer kapsamlı gelir unsurlarının toplam kapsamlı gelir ve kârlılık oranları üzerindeki etkisinin çalışma kapsamında analiz edilmiş olması da literatüre katkı sağlayacak diğer bir husustur.

Çalışmanın ikinci bölümünde kapsamlı gelir kavramının tarihsel gelişimi anlatılmıştır. Üçüncü bölümde diğer kapsamlı gelir unsurları kısaca açıklanmıştır. Dördüncü bölümde literatür incelemesi özetlenmiştir. Beşinci bölümde çalışmanın amacı, hipotezleri ve örneklem seçimi ile ilgili bilgi sunulmuştur. Altıncı bölümde analiz ve tartışma yer almıştır. Yedinci bölümde yer alan sonuçlar ve gelecekteki araştırmalar için öneriler ile çalışma sonlandırılmıştır.

\section{Kapsamlı Gelir Kavramının Tarihsel Gelişimi}

Amerikan Finansal Muhasebe Standartları Kurulu (FASB), 1981 ve 1993 yılları arasında kirli özkaynaklar yaklaşımı olarak adlandırılan bir yöntem ile gerçekleşmemiş gelir ve giderlerin doğrudan özkaynaklarda raporlanmasını öngören dört yeni standart yayınlamıştır (Sarığlu ve Türel, 2012: 86). 1997 yılında ise FASB kapsamlı gelirin ve unsurlarının raporlanmasını gerektiren SFAS 130 Kapsamlı Gelir Raporlama adıyla yeni bir standart yayınlamıştır (Bhamornsiri ve Wiggins, 2001). FASB'ın yayınladığı bu standart, işletmelerin kapsamlı gelir kalemlerini bilançoda özkaynaklar içerisinde değil ayrı bir şekilde raporlamasını gerektirmiştir (Kreuze ve Newell, 1999: 53).

UMS 1 Muhasebe Politikalarının Açıklamaları adıyla Uluslararası Muhasebe Standartları Kurulu (IASB) tarafından ilk kez 1975 yılında yürürlüğe konmuş ve zaman içinde değişiklikler geçirerek günümüze kadar gelmiştir (Doğan ve Ertugay, 2010). IASB, 2001 yılında Performans Raporlama Projesini başlatmıştır ve 2002 yılında proje ile ilgili ilk taslağ1 yayınlamıştır (Çetinoğlu ve Tutkavul, 2013: 147). Yayınlanan bu taslakta dönem kârı ile kapsamlı gelir kalemleri karşılaştırılmış ve geleneksel gelir tablosunda raporlanan dönem kârının işletmenin performansını değerlendirmek için tek başına yeterli olmayacağı belirtilmiştir (Çetinoğlu ve Tutkavul, 2013: 147). IASB'ye göre, toplam kapsamlı gelir işletmenin performansını geleneksel dönem kârına göre daha doğru bir şekilde yansıtmaktadır (Demir vd., 2013: 75). UMS 1 Finansal Tabloların Sunuluşu standardı 2007'de revize edilmiş ve 1 Ocak 2009'da yeni haliyle yayınlanmıştır (Ulusan, 2013: 46). Son değişikliklerden sonra UMS 1 doğrultusunda sunulacak gelir tablosu kalemlerinin kapsamı genişletilmiş ve standartta kapsamlı gelir tablosu ifadesine yer verilmiştir (Kaplanoğlu, 2014). UMS 1'de yapılan değişiklikler, IASB ve FASB'ın tek bir uluslararası finansal raporlama standart seti oluşturmak için birlikte yürüttükleri yakınsama projesinin bir yansımasıdır (Frendzel ve Szychta, 2013: 7).

Türkiye'de ise UMS 1 standardı, Türkiye Muhasebe Standartları Kurulu (TMSK) tarafından Türkçeye çevrilmiş ve TMS 1 Finansal Tabloların Sunuluşu standardı olarak 31 Aralık 2005 tarihinden sonra başlayan hesap dönemlerinde uygulanmak üzere 16 Ocak 2005 tarih ve 25702 sayılı Resmi Gazetede yayınlanarak yürürlüğe girmiştir. Daha sonra yapılan bazı değişiklikler, 12 Nisan 2006 tarih ve 26137 sayılı Resmi Gazetede ve 15 Temmuz 2007 tarih ve 26538 sayılı Resmi Gazetede yayınlanmıştır (Öztürk, 2009: 92). Kapsamlı gelirin raporlanmasına ilişkin değişiklikleri kapsayan TMS 1 standard1, 31 Aralık 2008 tarihinden başlayan hesap dönemleri için geçerli olmak üzere 13 Ağustos 2008 tarih ve 26966 sayılı Resmi Gazetede yayınlanmıştır. Bu standardın yürürlüğe girmesi BIST’te işlem gören işletmelerin diğer kapsamlı gelir kalemlerini kapsamlı gelir tablosunda raporlamasını zorunlu kılmıştır. Daha sonra, bu standartta 2012 yılında bazı değişiklikler yapılmış ve bu değişiklikler 29 Haziran 2012 tarih ve 28338 sayılı Resmi Gazetede yayınlanan “Türkiye Muhasebe Standartları Hakkında Tebliğlerde Değişiklik Yapılmasına İlişkin Tebliğ Sıra No:1" ile yürürlüğe girmiştir. Son olarak, TMS 1 Finansal Tabloların Sunuluşu standardı 2018 yılında Kamu Gözetimi Kurumu (KGK)'nun revizyon projesi kapsamında yeniden kaleme alınmış ve 24 Mayıs 2018 tarih ve 30430 sayılı Resmi Gazetede yayınlanmıştır (KGK, 2018). 


\section{Diğer Kapsamlı Gelir Unsurları}

UMS 1 kapsamında, özkaynaklarda gerçekleşen değişimler ortakların ortak olmaları nedeniyle ve ortakların ortak olmaları dişında ortaya çıkan işlemler olarak iki boyutta incelenmektedir (Ulusan, 2013: 49). FASB, 1985 yılında yayınladığı standarda göre kapsamlı geliri işletmenin belirli faaliyet dönemi boyunca ortaklarının sağladığı kaynaklar haricindeki özkaynak değişimleri olarak tanımlamıştır (FASB, 1985, bölüm 70). 2007 yılına kadar diğer kapsamlı gelir unsurları kirli unsurlar olarak gruplandırılmış ve kirli özkaynak kalemleri olarak sadece özkaynak değişim tablosunda gösterilmiştir (De Cristofaro ve Falzago, 2014). Kirli özkaynaklar grubunda yer alan kalemler özsermayede artış veya azalış oluşturmakla birlikte henüz gelir ve gider tanımlarına uymadıkları için normal gelirler veya giderler olarak raporlanmamışlardır (Kaval, 2011).

Gerçekleşmemiş gelirler arasında yer alan maddi ve maddi olmayan duran varlık değer artışları sermaye yedeği, satışa hazır finansal varlık değer artış ve azalışları, kur çeviri farkları ve aktüeryal kazanç ve kayıplar kâr yedeği niteliğindedir (Bayri, 2010: 101). Yani, diğer kapsamlı gelir unsurları özkaynaklarda artışa neden olan sermaye ve kâr yedeği niteliğindeki kâr ya da zararda muhasebeleştirilmeyen gelir ve gider (yeniden sınıflandırma düzeltmeleri de dâhil olmak üzere) kalemlerini kapsamaktadır (Gökgöz, 2013). Toplam kapsamlı gelir ise diğer kapsamlı gelir unsurlarının geleneksel gelir tablosunda yer alan dönem kârına eklenmesi sonucunda elde edilen tutar olarak hesaplanmaktadır (Fernández ve Arana, 2010).

Diğer kapsamlı gelir unsurları ileride kâr veya zarara aktarılabilecek durumda olan kalemler ile hiçbir şekilde kâr veya zarara aktarılamayacak olan kalemler olarak sınıflandırılmaktadırlar (Gökgöz, 2013: 25). UMS/UFRS'ye göre diğer kapsamlı gelirde yer alan ve hiçbir durumda kâr veya zarar içerisine aktarılamayacak olan diğer kapsamlı gelir unsurları aşağıdaki listede gösterilmiştir:

1. Maddi duran varlıklar yeniden değerleme fazlasındaki değişimler (UMS 16),

2. Maddi olmayan duran varlıklar yeniden değerleme fazlasındaki değişimler (UMS 38),

3. Tanımlanmış fayda planlarındaki aktüeryal kazanç ve kayıplar (UMS 19),

4. Özkaynağa dayalı finansal araçlardaki yatırımların gerçeğe uygun değer farklarından kaynaklanan kazanç ve kayıplar (UFRS 9) veya satışa hazır finansal varlıklar değerleme farkları (UMS 39),

UMS/UFRS'ye göre diğer kapsamlı gelirde yer alan ve ileride kâr veya zarar içerisine aktarılacak durumda olan diğer kapsamlı gelir unsurları ise şu şekildedir:

1. D1ş ülkedeki bağlı işletmeye ait finansal tabloların çevrilmesinden kaynaklanan kazanç ve kayıplar (UMS 21),

2. Nakit akış riskine ilişkin riskten korunma araçlarına bağlı olarak oluşan kazanç ve kayıpların etkin kısımları (UMS 39).

FASB'ın 1997 yılında yayınladığı SFAS 130, işletmelere kapsamlı gelir unsurlarını raporlamayabilmeleri için üç alternatif sunmuştur. Buna göre, işletmeler kapsamlı gelir unsurlarını özkaynak değişim tablosunda, geleneksel gelir tablosunda (tek tablo format1), ayrı bir kapsamlı gelir tablosunda (iki tablo formatı) olmak üzere üç farklı şekilde raporlayabilmektedirler (Marchini ve D'este, 2015). Kapsamlı gelir unsurları, doğrudan özkaynak değişim tablosunda raporlanınca, dönemin tüm gelir ve giderleri, finansal tablo kullanıcıların dikkatine yeterli bir şekilde sunulmamış olacaktır (Kaval, 2011). Bu nedenle, UMS 1'de SFAS 130'da yer alan bu yaklaşımlardan sadece ikisi benimsenmiştir. UMS 1'e göre, işletmeler diğer kapsamlı gelir unsurlarını tek tablo veya iki tablo formatında raporlayabileceklerdir (Schaberl ve Victoravich, 2015: 239). Yani, standartta kapsamlı gelirin tek tablo veya iki tablo formatında raporlanmas1 hususu işletmelerin tercihine bırakılmıştır. Tek tabloda sunumu tercih eden işletmeler, kapsamlı gelir kalemleri dâhil bütün gelir ve gider kalemlerini tek bir tabloda gösterebilmektedirler (Doğan ve Ertugay, 2010). İki tablo formatını tercih eden işletmeler ise kapsamlı gelir unsurlarını geleneksel gelir tablosuna ek olarak dönem net kârı (zararı) ile başlayan ayrı bir tabloda sunabileceklerdir (Sarığlu ve Türel, 2012: 87).

Kapsamlı gelir unsurlarının geleneksel gelir tablosunun bir parçası olarak değil de ayrı olarak raporlanmasının çeşitli sebepleri vardır. İlk olarak, bu tür gelirler işletme yönetiminin başarısının sonucu değil, işletme dışında meydana gelen olayların sonucu olarak oluşurlar (Kaval, 2011). Bu nedenle, diğer kapsamlı gelir kalemlerini geleneksel gelir tablosunda yer alan diğer gelir veya gider kalemleri ile birlikte raporlamak işletmenin performansının değerlendirilmesi açısından yanıltıcı sonuçlar doğurabilir. Ayrıca, diğer kapsamlı gelir unsurlarının farklı bir tabloda gösterilmeden geleneksel gelir tablosuna ek olarak yayınlanması dönem kârı (zararı) tutarının gölgelenmesine neden olabilir (Ferraro, 2011).

\subsection{Maddi ve Maddi Olmayan Duran Varlıklar Yeniden Değerleme Fazlasındaki Değişimler}

UMS 16 Maddi Duran Varlıklar ve UMS 38 Maddi Olmayan Duran Varlıklar standartlarında işletmeler maddi duran varlıklarını maliyet modeli veya yeniden değerleme modeline göre değerleyebilmektedirler (Pamukçu, 2011: 92). Maddi ve maddi olmayan yeniden değerleme fazlasındaki değişimler, söz konusu varlıkların UMS 16 ve UMS 38 standartları kapsamında yeniden değerleme modeline göre değerlenmesi sonucunda ortaya çıkan değişimlerdir (Gökgöz, 2013: 26).

\subsection{Tanımlanmış Fayda Planlarındaki Aktüeryal Kazanç ve Kayıplar}

UMS 19 Çalışanlara Sağlanan Faydalar standardı, işletmelerin aldıkları hizmet karşılığında çalışanlarına sağladıkları her türlü bedeli fayda olarak tanımlamakta ve söz konusu faydaların nasıl raporlanacağına ilişkin hususları kapsamaktadır (Durgut ve Kaya, 2013: 179). Standartta çalışanlara sağlanan dört temel faydadan bahsedilmektedir. Bunlar:

1. Çalışma döneminde sağlanan kısa vadeli faydalar (ücret, maaş, ücretli hastalık izni, sağlık yardımı vb.), 
2. Çalışma dönemi sonrasında sağlanan faydalar (emekli maaşı, emeklilik ikramiyesi, emeklilik sonrası sağlık yardımı, emeklilik sonrası hayat sigortası vb.),

3. Çalışanlara sağlanan diğer uzun vadeli faydalar (uzun süreli işten ayrılmalar veya seyahat, iş göremezlik ödeneği, dönemin bitiminden itibaren on iki ay içinde tamamı ödenmeyen kâr paylaşımı, ikramiye ve ertelenmiş ödemeler vb.) ve

4. İşten çıkarma (kıdem ve ihbar) tazminatları.

İşletmeler, UMS 19 kapsamında çalışanlara sağlanan faydaları doğru ve gerçekçi hesaplayabilmek için önemli bir düzeyde aktüeryal ve olasılık hesaplama bilgisine ihtiyaç duymaktadırlar (Zeytinoğlu vd., 2015: 738). Hesaplamada kullanılan tahminlerin zamana bağlı olarak değişmesi sonucunda ortaya çıkan farklılıklar aktüeryal kazanç ve kayıp olarak adlandırılmaktadır (Zeytinoğlu vd., 2015: 738).

\subsection{Kur Değişim Farkları}

Yabancı para çevrim farklarının muhasebeleştirilmesi altında günlük işlemlerin muhasebeleştirilmesi, dönem sonu değerleme ve finansal tabloların farklı para birimine çevrilmesi gibi başlıklar yer almaktadır (Gürkan ve Köse, 2013: 274). Yabancı ülkede faaliyet gösteren bağlı ortaklıklar, bulundukları ülkenin mevzuatına ve para birimine uygun finansal raporlama gerçekleştirirler (Doğan ve Ertugay, 2010: 132). Bu işletmelerin finansal tablolarının farklı para birimine çevrilmesi sonucunda oluşan kur farkları, başlangıçta diğer kapsamlı gelirin bir unsuru olarak, net yatırımın elden çıkarılması durumunda ise kâr ya da zarar olarak raporlanmaktadır (Gürkan ve Köse, 2013: 274).

\section{4. Özkaynağa Dayalı Finansal Araçlar Gerçeğe Uygun Değer Farkları veya Satışa Hazır Finansal Varlıklar Değerleme Farkları}

Özkaynağa dayalı bir finansal araca yapılan yatırım alım satım amacıyla elde tutulmuyorsa, geri dönülmemek şartıyla gerçeğe uygun değerinde meydana gelen değişimler diğer kapsamlı gelir içerisinde yer alabilmektedir (Kaplanoğlu, 2014: 82). İştirakler ve bağlı ortaklıklar alım satım amacıyla elde tutulmayan özkaynağa dayalı finansal araçların en yaygın örneklerindendir ve iştiraklerdeki ve bağlı ortaklıklardaki yatırımların gerçeğe uygun değerlenmesi sonucu oluşan değerleme farklarının işletmeye düşen payları UFRS 9 standardı kapsamında diğer kapsamlı gelir içerisinde muhasebeleştirilmektedir (Gökgöz, 2013: 35).

\subsection{Nakit Akış Riskine İlişskin Riskten Korunma Araçlarına Bağlı Olarak Oluşan Kazanç ve Kayıplar}

Türev ürünler, işletmelerin geleceğe güvenle bakabilmeleri, varlıklarını sürdürebilmeleri ve geleceğe ilişkin doğru tahminler yapabilmeleri için risk yönetimi amacıyla kullandıkları araçlardır (Haftacı ve Pehlivanlı, 2007: 139). Türev ürünlerin riskten korunmak amacıyla kullanılmaları durumunda yapılan muhasebeleştirme işlemleri hedge muhasebesi olarak adlandırılmaktadır (Haftacı ve Pehlivanlı, 2007: 141). Nakit akış riskinden korunma, bilançoda yer alan bir varlığın ya da yükümlülüğün veya gerçekleşme olasılığı yüksek olan bir işlemin tahmini değerinin piyasa değerine göre değişim göstermesi sonucunda bir işletmenin katlanacağı nakit çıkış riskinin ortadan kaldırılmasına yönelik işlemleri ifade etmektedir (Doğan ve Ertugay, 2010: 125). İşletmelerin finansal riskten korunmak için yaptıkları futures, forward ve swap gibi türev sözleşmelerinin sonucunda ortaya çıkan kazanç ve kayıpların etkin kısımları diğer kapsamlı gelir olarak raporlanmaktadır (Gökgöz, 2013; Gürkan ve Köse, 2013; Kaplanoğlu, 2014). Finansal riskten korunma aracından kaynaklanan kazanç ve kaybın etkin olmayan kısımları ise doğrudan dönemin kâr veya zararı içerisinde raporlanır (Gürkan ve Köse, 2013: 277).

\section{Literatür İncelemesi}

Türkiye'de kapsamlı gelir ile ilgili gerçekleştirilen çalışmaların önemli bir kısmı kapsamlı gelir unsurlarının muhasebeleştirilmesi hususunu ele almıştır (Doğan ve Ertugay, 2010; Gökgöz, 2013; Kaplanoğlu, 2014; Küçük, 2015). Bunun yanı sıra, işletmelerin kapsamlı gelir uygulamalarını ampirik olarak inceleyen de çalışmalar vardır (Sarığlu ve Türel, 2012; Çetinoğlu ve Tutkavul, 2013; Ulusan, 2013; Köse ve Gürkan, 2014).

Sarıoglu ve Türel (2012) gerçekleştirdikleri araştırma ile kapsamlı gelir tablosunun içeriğinde yer alan Türkçe kavramların istenen anlamı ne ölçüde ifade ettiği hususunu ele almışlardır. Ayrıca, çalışmalarında Türkiye'de faaliyet gösteren halka açık işletmelerin 2009 ve 2011 yılı kapsamlı gelir tablolarını ve raporladıkları diğer kapsamlı gelir unsurlarını analiz etmişlerdir. Araştırmanın sonuçları, işletmelerin kapsamlı gelirlerini sunarken çoğunlukla tek tablo formatını tercih ettiklerini göstermiştir. Bunun yanı sıra, diğer kapsamlı gelir unsurlarının toplam kapsamlı geliri çoğunlukla pozitif yönde etkilediği sonucu tespit edilmiştir.

Çetinoğlu ve Tutkavul (2013) gerçekleştirdikleri çalışmada diğer kapsamlı gelir unsurlarının BİST’te işlem gören 42 adet aracı kurumun mali tablolarına etkisini incelemişlerdir. Bu amaçla, aracı kurumların kapsamlı gelir tablolarında yer alan kalemleri 2005-2010 yıllarını kapsayan bir süreç için analiz etmişlerdir. Analiz sonuçlarına göre, diğer kapsamlı gelir unsurları, dönem kârı ve toplam kapsamlı gelir arasında 2008 ve 2010 yıllarında istatistiki olarak anlamlı bir fark oluşturmazken, 2009 yılında anlamlı bir fark oluşturmuştur.

Ulusan (2013) gerçekleştirdiği araştırma kapsamında BİST’te işlem gören işletmelerin kapsamlı gelir raporlamada hangi yöntemi kullandıklarını ve kapsamlı gelirin finansal performans raporlama üzerindeki etkisini finansal kuruluşlar ile diğer şirketleri karşılaştırarak analiz etmiştir. Çalışmanın sonuçlarına göre, kapsamlı geliri tek tablo ve iki tablo formatına göre sunan işletme sayısı birbirine oldukça yakındır. Ayrıca, şirketlerin yaklaşık olarak yarısında kapsamlı gelir finansal performans raporlamasını önemli ölçüde etkilemektedir. Kapsamlı gelirde en önemli ağırlığa sahip olan unsur ise yabancı para çevrim farklarındaki değişimlerdir. 
Köse ve Gürkan (2014) çalışmalarında kapsamlı gelirin işletmelerin piyasa değerini açıklama konusundaki etkisini incelemişlerdir. Bu amaçla, 2008 ve 2013 yılları arasında BİST’te işlem gören işletmelerin verilerini analiz etmişlerdir. Araştırmanın sonuçları, işletmelerin piyasa değerleri ile kapsamlı gelirleri arasında istatiksel olarak anlamlı bir ilişki olduğunu göstermiştir.

Uluslararası literatürde diğer kapsamlı gelir ve unsurlarını inceleyen çok sayıda ampirik çalışma mevcuttur. Bu çalışmalardan bazıları kapsamlı gelir tutarı ile piyasa değeri arasındaki ilişkiyi ele almıştır (Cahan vd., 2000; Dastgir ve Valeshani, 2008; Kanagaretnam vd., 2009; Kubota vd., 2011; De Cristofaro ve Falzago, 2014). Uluslararası literatürde yer alan diğer bazı çalışmalar ise toplam kapsamlı gelir ve geleneksel dönem kârının ve toplam kapsamlı gelir ve geleneksel dönem kârı baz alınarak hesaplanan kârlılık oranlarının istatiksel olarak farklılaşıp farklılaşmadığını incelemiştir (Kreuze ve Newell, 1999; Fernández ve Arana, 2010; Ferraro, 2011; Frendzel ve Szychta, 2013; De Cristofaro ve Falzago, 2014; Ngmenipuo ve Issah, 2014; Păşcan, 2014; Marchini ve D’este, 2015; Ngmenipuo ve Issah, 2015).

Kreuze ve Newell (1999) çalışmalarında Fortune 500'de yer alan işletmelerden 100'nü rastgele örnekleme yöntemi ile seçerek kapsamlı gelir uygulamalarını analiz etmişlerdir. Çalışmanın sonuçlarına göre, işletmelerin birçoğunun dönem kârı tutarları ile toplam kapsamlı gelir tutarları birbirinden farklılaşmaktadır. Ancak, bu farklılık çok sayıda işletme için düşük bir düzeydedir.

Fernández ve Arana (2010) İspanya borsasında işlem gören işletmelerin kapsamlı gelirinin özkaynak kârlılığına etkisini analiz etmişlerdir. Analiz sonuçları, toplam kapsamlı gelir baz alınarak hesaplanan özkaynak kârlılığının geleneksel kâr baz alınarak hesaplanan özkaynak kârlılığından 2005, 2007 ve 2008 yıllarında istatistiki olarak farklılaştığını göstermiştir. Özellikle küresel finansal krizin yaşandığı 2008 yılında iki oran arasındaki farkın anlamlılık derecesinin diğer yıllara göre daha yüksek olduğu tespit edilmiştir.

Ferraro (2011) çalışmasında İtalya borsasında işlem gören işletmelerin UMS 1'i yayınlandıktan sonraki kapsamlı gelir uygulamalarını analiz etmiştir. Çalışmanın sonuçlarına göre, işletmelerin birçoğu diğer kapsamlı gelirlerini iki tablo formatında sunmayı tercih etmektedir. Ayrıca, işletmelerin büyüklüğünün ve diğer kapsamlı gelir tutarının pozitif veya negatif olmasının tablo format tercihinde etkilediği sonucu elde edilmiştir.

Frendzel ve Szychta (2013) Polonya borsasında işlem gören işletmelerin kapsamlı gelir raporlama uygulamalarını analiz etmişlerdir. Çalışmanın sonuçları, işletmenin büyüklüğü ile kapsamlı gelirin sunum formatı ve işareti (negatif veya pozitif olması) arasında anlamlı bir korelasyon olmadığını göstermiştir. Ayrıca, toplam kapsamlı gelir ve diğer kapsamlı gelir unsurları işletmelerin özkaynakları üzerinde önemli bir etki oluşturmamaktadır.

Ngmenipuo ve Issah (2014) gerçekleştirdikleri çalışmada Gana borsasında işlem gören işletmelerin kapsamlı gelir raporlama uygulamalarını incelemişlerdir. Araştırma bulguları, işletmelerin kapsamlı gelir unsurlarını daha çok tek tablo formatında ve fonksiyon esasına göre raporladıklarını göstermiştir.

De Cristofaro ve Falzago (2014) İtalya borsasında işlem gören işletmelerin 2009 ve 2011 yılları arasındaki kapsamlı gelir raporlama uygulamalarını incelemişlerdir. Çalışmanın sonuçlarına göre, işletmeler kapsamlı gelirlerini çoğunlukla iki tablo formatında sunmakta ve tablo formatlarını nadiren değiştirmektedirler. Ayrıca, işletmelerin kapsamlı gelirlerinin tutarı veya işareti (pozitif veya negatif olması) tablo format tercihini etkilememekte ya da çok az düzeyde etkilemektedir.

Păşcan (2014) Romanya borsasında işlem gören işletmelerin dönem kârları ile toplam kapsamlı gelirleri arasında anlamlı bir fark olup olmadığını t-testi ile analiz etmiştir. Ayrıca, toplam kapsamlı gelirin işletmelerin piyasa değerine etkisini incelemiştir. Çalışmanın sonuçları, işletmelerin dönem kârları ve toplam kapsamlı gelirleri arasında istatistiki olarak anlamlı bir fark olmadığını göstermiştir. Bunun yanı sıra, işletmelerin dönem kârlarının piyasa değerini açıklama oranı toplam kapsamlı gelire göre daha yüksektir.

Marchini ve D'este (2015) toplam kapsamlı gelir tutarlarının işletmelerin performans ölçütlerine etkisini analiz etmişlerdir. Bu amaçla, İtalya borsasında işlem gören işletmelerin finansal tablolarını 2007 ve 2012 yıllarını kapsayan bir süreç için incelemişlerdir. Araştırma sonuçlarına göre, işletmelerin toplam kapsamlı gelirleri özkaynak kârlılık oranlarını 2009 yılı hariç istatistiki olarak anlamlı bir şekilde etkilemektedir.

Ngmenipuo ve Issah (2015) gerçekleştirdikleri çalışmada Gana borsasında işlem gören işletmelerin diğer kapsamlı kalem tutarlarının performans ölçütlerine etkisini t-testi ile analiz etmişlerdir. $\mathrm{Bu}$ amaçla, 34 adet işletmenin finansal tablolarını incelemişlerdir. Araştırmanın bulguları, diğer kapsamlı gelirin hisse başına getiri veya özkaynak kârlılığı gibi performans göstergelerine istatistiki olarak anlamlı bir etkisinin olmadığını göstermiştir.

\section{5. Çalışmanın Amacı, Hipotezleri ve Örneklem}

\section{1. Çalışmanın Amacı}

Bu çalışmanın amacı, BİST’te işlem gören işletmelerin kapsamlı gelir raporlaması ile ilgili uygulamalarını incelemektir. İlk olarak, diğer kapsamlı gelir unsurlarını raporlayan işletmelerin tek tablo ve iki tablo formatından hangisini tercih ettikleri belirlenmiştir. Daha sonra, işletmelerin diğer kapsamlı gelir unsurlarını raporlama düzeyleri incelenmiştir.

Bu çalışmanın diğer bir amacı kapsamlı gelir unsurlarının dönem kârı tutarını hangi yönde etkilediğini ve toplam kapsamlı gelir üzerinde nasıl bir etki oluşturduğunu tespit etmektir. Bu amaçla, geleneksel dönem kârı tutarları ile toplam kapsamlı gelir tutarları arasındaki fark istatistiki olarak analiz edilmiştir. Ayrıca, geleneksel dönem kârı tutarları ve toplam kapsamlı gelir tutarları üzerinden hesaplanan özkaynak kârlılık oranları istatistiki olarak karşılaştırılmış ve anlamlı bir fark olup olmadığı gözlenmiştir. 


\section{2. Çalışmanın Hipotezleri}

FASB ve IASB, diğer kapsamlı gelir unsurlarının sunulmasına önem vermekte ve geleneksel gelir tablolarına ek olarak farklı bir tabloda raporlanmalarını işletmelerin tercihine bırakmaktadırlar. Bu durum, standart otoritelerinin geleneksel dönem kârını işletme performansını değerlendirme açısından yeterli bulmadıklarının ve toplam kapsamlı geliri yeni bir performans ölçütü olarak önemsediklerinin göstergesidir (Ngmenipuo ve Issah, 2015).

Geleneksel gelir tablosunda yer alan dönem kârı ile diğer kapsamlı gelir unsurlarının eklenmesi sonucu ortaya çıkan toplam kapsamlı gelir arasında istatistiki olarak anlamlı bir fark olup olmadığı dikkat çeken bir konu olmuştur. Literatürde yer alan çalışmalarda geleneksel dönem kârı ile toplam kapsamlı gelir arasındaki fark ile ilgili çelişkili sonuçlar elde edilmiştir. Păşcan (2014) geleneksel dönem kârı ile toplam kapsamlı gelir arasında istatistiki olarak anlamlı bir fark tespit edememiştir. Bunun yanı sıra, Fernández ve Arana (2010) geleneksel dönem kârı ile toplam kapsamlı gelirler arasında istatistiki olarak anlamlı bir fark olduğunu tespit etmişlerdir. Çetinoğlu ve Tutkavul (2013) ise 2009 yllı için dönem kârı ve toplam kapsamlı gelir arasında istatistiki olarak anlamlı bir fark bulurken 2008 ve 2010 yıllarında anlamlı bir fark tespit edememişlerdir. Bu çalışmada, geleneksel dönem kârı ile toplam kapsamlı gelir arasında istatistiki olarak anlamlı bir fark olup olmadığını test etmek için aşağıdaki hipotez geliştirilmiştir:

Hipotez 1a. Dönem kârı ile toplam kapsamlı gelir arasında anlamlı bir fark vardır.

Ayrıca, literatürde yer alan bazı çalışmalar doğrultusunda (Fernández ve Arana, 2010; Gazzola ve Amelio, 2014; Marchini ve D'este, 2015; Ngmenipuo ve Issah, 2015), bu çalışmada geleneksel dönem kârı baz alınarak hesaplanan özkaynak kârlılığı $\left(\mathrm{ÖKK}_{1}\right)$ ile toplam kapsamlı gelir baz alınarak özkaynak kârlılığı (ÖKK 2 ) arasındaki fark da istatistiki olarak incelenmiştir. Özkaynak kârlılık oranları arasında istatistiki olarak anlamlı bir fark olup olmadığını test etmek için aşağıdaki hipotez geliştirilmiştir:

Hipotez 1b. ÖKK 1 ve ÖKK 2 arasında istatistiki olarak anlamlı bir fark vardır.

ÖKK $_{1}$ geleneksel gelir tablosunda yer alan dönem net kârının özkaynaklara oranı, ÖKK 2 toplam kapsamlı gelirin özkaynaklara oranı olarak hesaplanmıştır.

\section{3. Örneklem}

Çalışma kapsamında BİST’te işlem gören işletmelerin kapsamlı gelir tablosunda sundukları unsurların incelenmesi hedeflenmiştir. Finansal kuruluşlar, holdingler ve sportif kulüp şirketleri farklı faaliyet ve finansal yapılarından dolayı analize dâhil edilmemiştir. Ayrıca, diğer kapsaml geliri sıfır olan işletmeler de örneklemde yer almamıştır. Sonuç olarak, çalışmanın örneklemini 2009 ile 2017 yılları arasında kalan tüm yıllar için diğer kapsamlı gelir bilgisi mevcut olan 53 adet işletme oluşturmuştur. Örneklem seçiminin ayrıntıları Tablo 1'de gösterilmiştir. Çalışmanın verileri işletmelerin finansal tablolarından elde edilmiştir.

Tablo 1. Örneklem Seçimi

\begin{tabular}{ll}
\hline Açılama & İşletme sayısı \\
\hline 31 Aralık 2018 tarihi itibariyle BİST’te işlem gören toplam işletme sayısı & 515 \\
Finansal kuruluşlar, holdingler ve sportif kulüp şirketleri hariç işletme sayısı & 286 \\
2009-2017 yılları arasında sürekli işlem gören işletme sayısı & 154 \\
2009-2017 yılları arasındaki tüm yıllar için kapsamlı gelir bilgisi mevcut olan işletme sayısı & 53 \\
\hline
\end{tabular}

\section{Analiz ve Tartışma}

\section{1. İşletmelerin Diğer Kapsamlı Gelir Unsurlarını Raporlama Uygulamaları}

Çalışmanın örnekleminde yer alan işletmelerin kapsamlı gelir tablosunu hangi formatta hazırladıkları incelenmiştir. İnceleme ile ilgili sonuçlar Tablo 2'de sunulmuştur. Bu sonuçlara göre, 2009 ve 2012 yılları arasında tek tablo ve iki tablo formatını tercih eden işletme sayısı birbirine eşit olarak seyretmiştir. Bu yıllarda tek tablo formatını tercih eden işletme sayısı $27(\% 50,94)$ iken, iki tablo formatını tercih eden işletme sayısı $26(\% 49,06)$ olarak tespit edilmiştir. 2013 ve 2017 yılları arasında ise iki tablo formatını tercih eden işletme sayısında sürekli artış yaşanmıştır. 2013 yılında iki tablo formatını tercih eden işletme sayısı 29 (\%54,72)'a, 2017 yılında ise 33 (\%62,26)'e çıkmıştır.

Araştırma bulguları, UMS 1 standardının ilk uygulama yıllarında tek tablo ve iki tablo formatını tercih eden işletme sayısının eşit, sonraki yıllarda ise iki tablo formatını tercih eden işletme sayısının daha yüksek olduğunu göstermiştir. Kapsamlı gelir sunum formatı işletmelere bırakılmış olsa da literatürde diğer kapsamlı gelir unsurlarının geleneksel dönem kârını gösteren tabloya ek olarak farklı bir tabloda raporlanmasının çeşitli faydaları sunulmuştur. İşletmelerin diğer kapsamlı gelir unsurlarını iki tablo formatında sunmaları, gerçekleşmiş ve gerçekleşmemiş gelirlerin ayrımının finansal tablo kullanıcılar tarafından daha net bir şekilde yapılmasını (Ferraro, 2011); raporlamada daha şeffaf olunmasını (Ulusan, 2013); geleneksel gelir tablosunda yer alan dönem kârının geçici kalemler ile gölgelenmemesini (Ferraro, 2011) sağlayacaktır. Bu nedenle, kapsamlı gelirlerini iki tablo formatında sunmayı tercih eden işletme sayısında gözlenen artış olumlu bir bulgu olarak değerlendirilebilir. 
Tablo 2. Kapsamlı Gelirin Sunum Şekli

\begin{tabular}{ccccc}
\hline & \multicolumn{2}{c}{ Tek tablo } & \multicolumn{2}{c}{ Iki tablo } \\
\hline & $\mathrm{N}$ & $\%$ & $\mathrm{~N}$ & $\%$ \\
\hline 2009 & 27 & 50,94 & 26 & 49,06 \\
2010 & 27 & 50,94 & 26 & 49,06 \\
2011 & 27 & 50,94 & 26 & 49,06 \\
2012 & 27 & 50,94 & 26 & 49,06 \\
2013 & 24 & 45,28 & 29 & 54,72 \\
2015 & 24 & 45,28 & 29 & 54,72 \\
2016 & 23 & 43,40 & 30 & 56,60 \\
2017 & 22 & 41,51 & 31 & 58,49 \\
\hline
\end{tabular}

İşletmelerin kapsamlı gelir tablolarında sundukları diğer kapsamlı gelir unsurları incelenmiştir. İşletmelerin diğer kapsamlı gelir unsurlarını sunum düzeyleri ile ilgili bilgilerin ayrıntıları Tablo 3 'te gösterilmiştir.

Analiz yıllarını kapsayan süreçte maddi ve maddi olmayan duran varlıklar yeniden değerleme fazlasındaki değişimler bilgisini sunan işletme sayısında önemli düzeyde bir değişiklik gözlenmiştir. 2009 yılında yeniden değerleme farklarını raporlayan işletme sayısı $10(\% 18,87)$ iken 2017 yılında bu sayı $22(42,51 \%)$ 'ye yükselmiştir.

2009 ve 2017 yılları arasında raporlanma oranında en fazla değişiklik olan diğer kapsamlı gelir unsuru aktüeryal kazanç ve kayıplar olarak tespit edilmiştir. 2009 yılında aktüeryal kazanç ve kayıplar bilgisini sunan işletme oranı sadece \%3,77 iken, 2017 y1lında bu oran \%94,34 olarak gerçekleşmiştir. Aktüeryal kazanç ve kayıp bilgisini kapsamlı gelir tablosunda sunan işletme sayısındaki artışın sebebi UMS 19 standardında 2013 yılında yapılan güncellemedir. 2012'de 12 olan aktüeryal kazanç ve kayıp kalemini raporlayan işletme sayısı, bu güncellemeyi takiben 2013'te 42'ye ulaşmıştır.

Analiz sürecinde yer alan tüm yıllar boyunca kur değişim farkları bilgisini raporlayan işletme oranının yaklaşık \%74 düzeyinde olduğu belirlenmiştir. Analiz sonuçları kur değişim farklarının işletmeler tarafından en fazla raporlanan diğer kapsamlı gelir unsuru olduğunu göstermiştir. Literatürde yer alan birçok çalışmada da kur değişim farkları işletmeler tarafından en fazla raporlanan ve toplam kapsamlı gelir üzerinde en büyük ağırlığa sahip olan diğer kapsamlı gelir unsuru olarak gösterilmiştir (Dumitrana vd., 2010; Sarığlu ve Türel, 2012; Ulusan, 2013).

Araştırma bulguları analiz sürecinde özkaynağa dayalı finansal araçlar gerçeğe uygun değer farkları veya satışa hazır finansal varlıklar değerleme farkları bilgisini sunan işletme sayısında belirgin bir değişiklik olmadığını göstermiştir. 2009 yılında bu bilgiyi raporlayan işletme oranı \%50,94 iken 2017 yılında bu oran \%37,74 olarak gerçekleşmiştir. Nakit akış riskine ilişkin riskten korunma araçlarına bağlı olarak oluşan kazanç ve kayıplar bilgisini raporlayan işletme oranı ise 2009 yılında \%16,98, 2017 yılında \%39,62 olarak tespit edilmiştir.

Sonuç olarak, işletmeler tarafindan en fazla raporlanan diğer kapsamlı gelir kalemleri aktüeryal kazanç ve kayıplar ve kur değişim farklart; en az raporlanan kalemler ise yeniden değerleme farkları, finansal araçların değerleme farkları ve nakit akış riskine ilişkin kazanç ve kayıplar olarak tespit edilmiştir.

Tablo 3. İşletmeler Tarafından Sunulan Kapsamlı Gelir Unsurları

\begin{tabular}{|c|c|c|c|c|c|c|c|c|c|c|}
\hline & \multicolumn{2}{|c|}{$\begin{array}{l}\text { Yeniden } \\
\text { değerleme } \\
\text { farkları }\end{array}$} & \multicolumn{2}{|c|}{$\begin{array}{l}\text { Aktüeryal } \\
\text { kazanç ve } \\
\text { kayıplar }\end{array}$} & \multicolumn{2}{|c|}{$\begin{array}{l}\text { Kur değişim } \\
\text { farklart }\end{array}$} & \multicolumn{2}{|c|}{$\begin{array}{l}\text { Finansal araçların } \\
\text { değerleme farkları }\end{array}$} & \multicolumn{2}{|c|}{$\begin{array}{c}\text { Nakit akış riskine } \\
\text { ilişkin kazanç ve } \\
\text { kayıplar }\end{array}$} \\
\hline & $\mathrm{N}$ & $\%$ & $\mathrm{~N}$ & $\%$ & $\mathrm{~N}$ & $\%$ & $\mathrm{~N}$ & $\%$ & $\mathrm{~N}$ & $\%$ \\
\hline 2009 & 10 & 18,87 & 2 & 3,77 & 39 & 73,58 & 27 & 50,94 & 9 & 16,98 \\
\hline 2010 & 12 & 22,64 & 2 & 3,77 & 38 & 71,70 & 24 & 45,28 & 10 & 18,87 \\
\hline 2011 & 14 & 26,42 & 4 & 7,55 & 39 & 73,58 & 20 & 37,74 & 14 & 26,42 \\
\hline 2012 & 16 & 30,19 & 12 & 22,64 & 39 & 73,58 & 21 & 39,62 & 18 & 33,96 \\
\hline 2013 & 21 & 39,62 & 42 & 79,25 & 39 & 73,58 & 18 & 33,96 & 23 & 43,40 \\
\hline 2014 & 11 & 20,75 & 47 & 88,68 & 39 & 73,58 & 17 & 32,08 & 23 & 43,40 \\
\hline 2015 & 23 & 43,40 & 48 & 90,57 & 39 & 73,58 & 21 & 39,62 & 23 & 43,40 \\
\hline 2016 & 17 & 32,08 & 48 & 90,57 & 40 & 75,47 & 23 & 43,40 & 20 & 37,74 \\
\hline 2017 & 22 & 42,51 & 50 & 94,34 & 38 & 71,70 & 20 & 37,74 & 21 & 39,62 \\
\hline Toplam & 146 & & 255 & & 350 & & 191 & & 161 & \\
\hline
\end{tabular}

Tablo 4'te işletmelerin geleneksel dönem kârlarının, diğer kapsamlı gelir unsurlarının ve toplam kapsamlı gelirlerinin ortalama tutarları sunulmuştur. Ortalama tutarlar incelendiğinde diğer kapsamlı gelirde yaşanan değişim dikkat çekmektedir. Diğer kapsamlı gelirin ortalama tutarı 2012 ve 2014 yıllarında negatif olarak gerçekleşirken, diğer yıllarda pozitif olarak gerçekleşmiştir. Özellikle 2013, 2015, 2016 ve 2017 yıllarında diğer kapsamlı gelir tutarlarının diğer yıllara oranla çok yüksek düzeyde gerçekleştiği tespit edilmiştir. Bir önceki tabloda (Tablo 3) gösterildiği üzere bu yıllarda diğer kapsamlı gelir unsurlarından yeniden değerleme farklarının daha fazla işletme tarafından sunulmuş olması diğer kapsamlı gelir düzeyinin diğer yıllara oranla daha yüksek tutarda gerçekleşmesine neden olmuş olabilir. Bu sonuca göre maddi ve maddi olmayan varlıkların yeniden değerleme farklarının toplam kapsamlı gelir düzeyi üstünde diğer kalemlere göre pozitif yönde daha fazla etki oluşturduğu söylenebilir. 
K1lıç, M. / Journal of Yasar University, 2019, 14/54, 127-140

Tablo 4. Dönem Kârı, Diğer Kapsamlı Gelir ve Toplam Kapsamlı Gelir Tutarları

\begin{tabular}{lrrr}
\hline & Dönem kârı $($ TL) & Diğer kapsamlı gelir $($ TL $)$ & Toplam kapsamli gelir (TL) \\
\hline 2009 & 169.807 .105 & 18.229 .216 & 188.036 .322 \\
2010 & 207.469 .830 & 21.357 .024 & 227.923 .092 \\
2011 & 200.387 .528 & 40.372 .671 & 240.767 .381 \\
2012 & 282.269 .699 & -2.835 .895 & 279.426 .896 \\
2013 & 281.617 .879 & 120.784 .096 & 398.476 .570 \\
2014 & 261.493 .521 & -14.168 .074 & 247.332 .889 \\
2015 & 308.444 .446 & 193.745 .848 & 502.542 .033 \\
2016 & 245.388 .139 & 232.027 .121 & 477.442 .662 \\
2017 & 436.685 .067 & 172.728 .658 & 609.413 .725 \\
\hline
\end{tabular}

2012 ve 2014 yıllarında diğer kapsamlı gelir tutarının negatif olarak gerçekleşmesine neden olan diğer kapsamlı gelir unsurlarının tespiti için bu iki yılın diğer kapsamlı gelir kalemlerinin ortalamaları hesaplanmıştır ve Tablo 5'te gösterilmiştir. 2012 yılında aktüeryal kazanç ve kayıplar ve kur değişim farkları, 2014 y1lında ise aktüeryal kazanç ve kayıplar, kur değişim farkları ve nakit akış riskine ilişskin kazanç ve kayıplar kalemlerinin negatif olarak gerçekleştikleri ve bu yıllardaki diğer kapsamlı gelir ortalamasının negatif çıkmasına neden oldukları tespit edilmiştir. Diğer kapsamlı gelir unsurları yıllar itibariyle farklılık gösteren ve devamlılık arz etmeyen kalemleri kapsamaktadır. Örneğin, aktüeryal kazanç ve kayıplar, aktüeryal varsayımlarda yaşanan bazı sapmalar nedeniyle ortaya çıktığından yıllar itibariyle devamlılık göstermesi beklenemez (Gürkan ve Köse, 2013: 273). Bu nedenle, bu kalemin bazı y1llarda farklılık göstermesi ve toplam kapsamlı gelir üstünde daha fazla negatif etki oluşturması şaşırtıcı değildir. 2012 ve 2014 yıllarında diğer kapsamlı gelirin negatif çıkmasına aktüeryal kazanç ve kayıplar, kur değişim farkları ve nakit akış riskine ilişkin kazanç ve kayıplar kalemlerinin negatif tutarlarının yanı sıra bu yıllarda diğer kalemlerin ortalama tutarlarının düşük düzeyde gerçekleşmiş olması da etkili olmuştur.

Tablo 5. Diğer kapsamlı gelir unsurları tutarları (2012-2014)

\begin{tabular}{lrr}
\hline Diğer kapsamlı gelir unsurlarl & 2012 & 2014 \\
\hline Yeniden değerleme farkları & 13.693 .396 & 4.032 .005 \\
Aktüeryal kazanç ve kayıplar & -2.851 .997 & -3.975 .333 \\
Kur değişim farkları & -28.835 .104 & -24.783 .967 \\
Finansal araçların değerleme farkları & 14.527 .848 & 13.218 .516 \\
Nakit akış riskine ilişkin kazanç ve kayıplar & 258.855 & -3.653 .075 \\
\hline
\end{tabular}

\subsection{Diğger Kapsamlı Gelir Unsurlarının Toplam Kapsamlı Gelir ve Kârlılık Oranları Üzerindeki Etkisi}

Diğer kapsamlı gelir unsurlarının dönem net kârı (zararı) üzerinde oluşturduğu etkinin derecesi ve yönü incelenmiştir. İnceleme sonuçları Tablo 6'da sunulmuştur. Ferraro (2011)'nun çalışması model alınarak, diğer kapsamlı gelir unsurlarının dönem net kârı (zararı) üzerindeki etkisi negatif etki ve pozitif etki olarak iki gruba ayrılmıştır. Negatif etki, kârdan zarara geçiş, kârda azalış ve zararda artış olarak; pozitif etki, zarardan kâra geçiş, kârda artış, zararda azalış olarak üç gruba ayrılmıştır.

Kârdan zarara geçiş, diğer kapsamlı gelir unsurlarının dönem net kârına eklenmesi sonrasında toplam kapsamlı zarar oluşması durumunu ifade etmektedir. Araştırma bulgularına göre, diğer kapsamlı gelir unsurlarının kârdan zarara geçişine neden olduğu işletme sayısı oldukça düşüktür. 2015 ve 2016 yıllarında kârdan zarara geçen işletme yoktur. 2012 ise kârdan zarara geçen işletme oranının \%5,7 ile en yüksek olduğu yıl olarak belirlenmiştir. Kârda azalış, diğer kapsamlı gelir unsurlarının dönem net kârına eklenmesi ile toplam kapsamlı kâr oluşması ancak tutarın düşmesi anlamına gelmektedir. Diğer kapsamlı gelir unsurlarının eklenmesi sonucunda kârında azalış gerçekleşen işletme oranı \%18,9 ile \%41,5 arasında değişkenlik göstermiştir. Zararda artış, diğer kapsamlı gelir unsurlarının dönem net zararına eklenmesi sonrasında toplam kapsamlı zararın daha yüksek bir tutar olması durumunu ifade etmektedir. Toplam kapsamlı gelir unsurlarının eklenmesi sonrasında dönem zararında artış olan işletme oranı en düşük \%1,9 en yüksek $\% 17,0$ olarak tespit edilmiştir.

Zarardan kâra geçiş, diğer kapsamlı gelir unsurlarının dönem net zararına eklenmesi ile toplam kapsamlı kâr oluşması durumunu ifade etmektedir. Analiz sonuçlarına göre, diğer kapsamlı gelir unsurları eklendikten sonra kârdan zarara geçen işletme oranının düşük olduğu gibi zarardan kâra geçen işletme oranın da düşük olduğu tespit edilmiştir. 2014 yılında zarardan kâra geçen işletme yoktur. 2015 ise zarardan kâra geçen işletme oranının \%11,3 ile en yüksek olduğu yıl olmuştur. Kârda artış, diğer kapsamlı gelir unsurlarının dönem net kârına eklenmesi ile birlikte toplam kapsamlı kârın daha yüksek bir tutar olmasıdır. Toplam kapsamlı gelir unsurlarının eklenmesi sonrasında dönem net kârında artış olan işletme oranı en düşük \%39,6 en yüksek \%62,3 olarak tespit edilmiştir. Zararda azalış, diğer kapsamlı gelir unsurlarının dönem net zararına eklenmesi sonrasında toplam kapsamlı zararın daha düşük bir tutar olması 
durumunu ifade etmektedir. Toplam kapsamlı gelir unsurlarının eklenmesi sonrasında dönem net zararında azalış olan işletme oranı \%1,9 ile \%15,1 arasında değişkenlik göstermiştir.

Bu sonuçlara göre, diğer kapsamlı gelir unsurlarının işletmelerin dönem net kârını zarara, dönem net zararını kâra dönüştürdüğü gözlem sayısı oldukça düşüktür. Diğer bir ifade ile diğer kapsamlı gelir unsurlarının dönem net kârı (zararı) değerinin yönü üzerindeki etkisi son derece kısıtlıdır. Ayrıca, yıllara göre değişkenlik gösterse de diğer kapsamlı gelir unsurları dönem net kârı üzerinde çoğunlukla pozitif bir etki göstermekte ve toplam kapsamlı gelir daha yüksek bir tutar olarak ortaya çıkmaktadır.

Tablo 6. Diğer Kapsamlı Gelir Unsurlarının Toplam Kapsamlı Gelir Üzerine Etkisi

\begin{tabular}{|c|c|c|c|c|c|c|c|c|c|c|c|c|c|c|c|c|c|c|}
\hline & \multicolumn{2}{|c|}{2009} & \multicolumn{2}{|c|}{2010} & \multicolumn{2}{|c|}{2011} & \multicolumn{2}{|c|}{2012} & \multicolumn{2}{|c|}{2013} & \multicolumn{2}{|c|}{2014} & \multicolumn{2}{|c|}{2015} & \multicolumn{2}{|c|}{2016} & \multicolumn{2}{|c|}{2017} \\
\hline & $\mathrm{N}$ & $\%$ & $\mathrm{~N}$ & $\%$ & $\mathrm{~N}$ & $\%$ & $\mathrm{~N}$ & $\%$ & $\mathrm{~N}$ & $\%$ & $\mathrm{~N}$ & $\%$ & $\mathrm{~N}$ & $\%$ & $\mathrm{~N}$ & $\%$ & $\mathrm{~N}$ & $\%$ \\
\hline \multicolumn{19}{|l|}{ Negatif etki } \\
\hline Kârdan zarara & 2 & 3,8 & 1 & 1,9 & 1 & 1,9 & 3 & 5,7 & 2 & 3,8 & 1 & 1,9 & 0 & 0,0 & 0 & 0,0 & 2 & 3,8 \\
\hline Kârda azalış & 18 & 34,0 & 14 & 26,4 & 14 & 26,4 & 22 & 41,5 & 11 & 20,8 & 16 & 30,2 & 13 & 24,5 & 15 & 28,3 & 10 & 18,9 \\
\hline Zararda artış & 5 & 9,4 & 1 & 1,9 & 3 & 5,7 & 4 & 7,5 & 2 & 3,8 & 9 & 17,0 & 2 & 3,8 & 8 & 15,1 & 4 & 7,5 \\
\hline \multicolumn{19}{|l|}{ Pozitif etki } \\
\hline Zarardan kâra & 1 & 1,9 & 2 & 3,8 & 1 & 1,9 & 2 & 3,8 & 3 & 5,7 & 0 & 0,0 & 6 & 11,3 & 5 & 9,4 & 2 & 3,8 \\
\hline Kârda artış & 25 & 47,2 & 31 & 58,5 & 26 & 49,1 & 21 & 39,6 & 30 & 56,6 & 25 & 47,2 & 28 & 52,8 & 23 & 43,4 & 33 & 62,3 \\
\hline Zararda azalış & 2 & 3,8 & 4 & 7,5 & 8 & 15,1 & 1 & 1,9 & 5 & 9,4 & 2 & 3,8 & 4 & 7,5 & 2 & 3,8 & 2 & 3,8 \\
\hline Toplam & 53 & & 53 & & 53 & & 53 & & 53 & & 53 & & 53 & & 53 & & 53 & \\
\hline
\end{tabular}

İşletmelerin geleneksel dönem kârları ile toplam kapsamlı gelirleri arasında istatistiki olarak fark olup olmadığı analiz edilmiştir. Normal dağılıma sahip gruplar arası farklar için parametrik testler kullanılırken, normal dağılıma sahip olmayan gruplar arası farklar için parametrik olmayan testler kullanılmaktadır. Bu doğrultuda öncelikle istatistiki analizlerde kullanılacak testlerin türünü tespit etmek amacı ile veriler tüm yıllar için Kolmogorov-Smirnov testi ile normallik analizine tabi tutulmuştur. Gerçekleştirilen bu testin sonuçları Tablo 7 'de sunulmuştur.

Tablo 7. Normallik testi sonuçları

\begin{tabular}{lccc}
\hline & \multicolumn{3}{c}{ Kolmogorov-Smirnov } \\
\hline & İstatistik değeri & Serbestlik derecesi & Anlamll1k düzeyi (p) \\
\hline Dönem kârı & 0,253 & 477 & 0,000 \\
Toplam kapsamlı gelir & 0,253 & 477 & 0,000 \\
ÖKK $_{1}$ & 0,299 & 477 & 0,000 \\
ÖKK $_{2}$ & 0,296 & 477 & 0,000 \\
\hline ÖKK
\end{tabular}

ÖKK $\mathrm{K}_{1}$ : Dönem net kârının özkaynaklara oranı

ÖKK $K_{2}$ : Toplam kapsamlı gelirin özkaynaklara oranı

Normallik testinin sonuçlarına göre geleneksel dönem kârı, toplam kapsamlı gelir ve kârlılık oranlarının normal bir dağılıma sahip olmadıkları belirlenmiştir $(\mathrm{p}<0,05)$. Bu nedenle, gruplar arası farkların tespiti için parametrik olmayan Wilcoxon işaretli sıralar toplamı ve işaret testi kullanılmıştır. Literatürde yer alan çalışmalarda da benzer analizler için Wilcoxon işaretli sıralar toplamı ve işaret testi kullanılmıştır (Fernández ve Arana, 2010; Çetinoğlu ve Tutkavul, 2013; Marchini ve D'este, 2015; Ngmenipuo ve Issah, 2015). Wilcoxon testi ile öncelikle dönem kârı ve toplam kapsamlı gelir arasındaki farkların tespiti için aşağıdaki hipotezler test edilmiştir:

$\mathrm{H}_{0}$ : Dönem kârı ile toplam kapsamlı gelir birbirinden farklı değildir.

$\mathrm{H}_{1}$ : Dönem kârı ile toplam kapsamlı kâr birbirinden farklıdır.

Analiz sonuçları Tablo 8'de sunulmuştur. Elde edilen sonuçlar geleneksel gelir tablosunda yer alan dönem kârı ile toplam kapsamlı gelir arasında 2012 ve 2014 yılları hariç istatistiki olarak anlamlı bir fark olduğunu göstermektedir. Bu sonuçlara göre, Wilcoxon testinin varsayımı gereği dönem kârı ile toplam kapsamlı gelirin birbirinden farklı olmadığını belirten sıfır hipotezi reddedilmiş ve alternatif hipotez kabul edilmiştir. Bu doğrultuda araştırma hipotezi, Hipotez 1a, 2012 ve 2014 haricindeki yıllar için kabul edilmiştir.

Tutarların farklılaştığı yıllarda kapsamlı gelirin sıra ortalaması ve toplamlarının dönem kârı sıra ortalaması ve toplamlarından daha yüksek olması, toplam kapsamlı gelirin dönem kârından daha yüksek olduğuna işaret etmektedir. $\mathrm{Bu}$ sonuçlar diğer kapsamlı gelir unsurlarının toplam kapsamlı gelir üzerinde pozitif bir etki oluşturduğunu doğrulamıştır. 
Kılıç, M. / Journal of Yasar University, 2019, 14/54, 127-140

Tablo 8. Diğer Kapsamlı Gelir Unsurlarının Toplam Kapsamlı Gelire Etkisi

\begin{tabular}{|c|c|c|c|c|c|c|}
\hline $\begin{array}{r}\text { Dönem kârl-Toplam } \\
\text { kapsamlı gelir }\end{array}$ & & $N$ & $\begin{array}{c}\text { Sira } \\
\text { ortalamast }\end{array}$ & Sira toplamı & $z$ & $\begin{array}{l}\text { Anlamlılık } \\
\text { düzeyi }(p)\end{array}$ \\
\hline \multirow[t]{3}{*}{2009} & Negatif sira ${ }^{a}$ & 24 & 21,50 & 516 & $-1,766$ & 0,077 \\
\hline & Pozitif sıra ${ }^{b}$ & 29 & 31,55 & 915 & & \\
\hline & Eşit ${ }^{c}$ & 0 & & & & \\
\hline \multirow[t]{3}{*}{2010} & Negatif sira ${ }^{a}$ & 15 & 18,93 & 284 & $-3,820$ & 0,000 \\
\hline & Pozitif sıra ${ }^{\mathrm{b}}$ & 38 & 30,18 & 1147 & & \\
\hline & $\mathrm{Eşit}^{\mathrm{c}}$ & 0 & & & & \\
\hline \multirow[t]{3}{*}{2011} & Negatif sira $^{a}$ & 17 & 25,71 & 437 & $-2,465$ & 0,014 \\
\hline & Pozitif sıra ${ }^{b}$ & 36 & 27,61 & 994 & & \\
\hline & $\mathrm{Eşit}^{\mathrm{c}}$ & 0 & & & & \\
\hline \multirow[t]{3}{*}{2012} & Negatif sira ${ }^{a}$ & 29 & 24,90 & 722 & $-0,058$ & 0,954 \\
\hline & Pozitif sıra ${ }^{b}$ & 24 & 29,54 & 709 & & \\
\hline & $\mathrm{Eşit}^{\mathrm{c}}$ & 0 & & & & \\
\hline \multirow[t]{3}{*}{2013} & Negatif sira ${ }^{a}$ & 14 & 23,00 & 322 & $-3,484$ & 0,000 \\
\hline & Pozitif sıra ${ }^{b}$ & 39 & 28,44 & 1109 & & \\
\hline & Eşit ${ }^{\mathrm{c}}$ & 0 & & & & \\
\hline \multirow[t]{3}{*}{2014} & Negatif sira ${ }^{a}$ & 26 & 23,88 & 621 & $-0,837$ & 0,403 \\
\hline & Pozitif sıra ${ }^{b}$ & 27 & 30,00 & 810 & & \\
\hline & Eşit ${ }^{\mathrm{c}}$ & 0 & & & & \\
\hline \multirow[t]{3}{*}{2015} & Negatif sira ${ }^{a}$ & 15 & 22,73 & 341 & $-3,315$ & 0,001 \\
\hline & Pozitif sıra ${ }^{b}$ & 38 & 28,68 & 1090 & & \\
\hline & Eşit ${ }^{\mathrm{c}}$ & 0 & & & & \\
\hline \multirow[t]{3}{*}{2016} & Negatif sira ${ }^{a}$ & 23 & 21,00 & 483 & $-2,058$ & 0,040 \\
\hline & Pozitif sıra ${ }^{b}$ & 30 & 31,60 & 948 & & \\
\hline & Eşit ${ }^{c}$ & 0 & & & & \\
\hline \multirow[t]{3}{*}{2017} & Negatif sira ${ }^{a}$ & 16 & 17,88 & 286 & $-3,802$ & 0,000 \\
\hline & Pozitif sıra ${ }^{\mathrm{b}}$ & 37 & 30,95 & 1145 & & \\
\hline & $\mathrm{Eşit}^{\mathrm{c}}$ & 0 & & & & \\
\hline
\end{tabular}

äönem kârı>Toplam kapsamlı gelir

${ }^{b}$ Dönem kârı<Toplam kapsamlı gelir

'Dönem kârı=Toplam kapsamlı gelir

Diğer kapsamlı gelir unsurlarının toplam kapsamlı gelir üzerinde oluşturduğu etkinin yanı sıra kârlılık oranları üzerindeki etkisi de incelenmiştir. Bu amaçla, Wilcoxon testi ile geleneksel dönem kârı üzerinden hesaplanan özkaynak kârlılık oranı ile toplam kapsamlı gelir üzerinden hesaplanan özkaynak kârlılık oranı arasındaki fark aşağıda sunulan hipotezler doğrultusunda test edilmiştir:

$\mathrm{H}_{0}$ : Dönem kârı ile hesaplanan özkaynak kârlılık oranı ile toplam kapsamlı gelir ile hesaplanan özkaynak kârlılık oranı birbirinden farklı değildir.

$\mathrm{H}_{1}$ : Dönem kârı ile hesaplanan özkaynak kârlılık oranı ile toplam kapsamlı gelir ile hesaplanan özkaynak kârlılık oranı birbirinden farklıdır.

Tablo 9'da sunulan analiz sonuçlarına göre, 2012 ve 2014 yıllarında dönem kârları ve toplam kapsamlı gelir tutarları arasında istatistiki bir fark tespit edilemediği gibi bu yıllar için hesaplanan kârlılık oranları arasında da anlamlı bir fark tespit edilememiştir. Wilcoxon testinin varsayımı gereği dönem kârı ile hesaplanan özkaynak kârlılık oranı ile toplam kapsamlı gelir ile hesaplanan özkaynak kârlılık oranının farklı olmadığını belirten sıfır hipotezi reddedilmiş ve alternatif hipotez kabul edilmiştir. Bu sonuçlar doğrultusunda araştırma hipotezi, Hipotez 1b, 2012 ve 2014 haricindeki yıllar için kabul edilmiştir.

Kârlılık oranlarında anlamlı fark tespit edilen y1llarda toplam kapsamlı gelir üzerinden hesaplanan özkaynak kârlılık oranlarının sıra ortalaması ve toplamlarının dönem kârı üzerinden hesaplanan özkaynak kârlılık oranlarının sıra ortalaması ve toplamlarından daha yüksek değerlere sahip oldukları görülmektedir. Bu sonuçlar kapsamlı gelir baz alınarak hesaplanan özkaynak kârlılık oranlarının daha yüksek olduğunu göstermektedir. Diğer bir ifade ile diğer kapsamlı gelir unsurları toplam kapsamlı gelirin üzerinden hesaplanan kârlılık oranlarının daha yüksek değerlerde gerçekleşmesini sağlamaktadır. 
K1lıç, M. / Journal of Yasar University, 2019, 14/54, 127-140

Tablo 9. Diğer Kapsamlı Gelir Unsurlarının Kârlılık Oranlarına Etkisi

\begin{tabular}{|c|c|c|c|c|c|c|}
\hline $\mathrm{ÖKK}_{1}-\mathrm{ÖKK}_{2}$ & & $N$ & $\begin{array}{c}\text { Sira } \\
\text { ortalamast }\end{array}$ & Stra toplamı & $z$ & $\begin{array}{l}\text { Anlamlılık } \\
\text { düzeyi (p) }\end{array}$ \\
\hline \multirow[t]{3}{*}{2009} & Negatif sira $^{a}$ & 11 & 11,09 & 122,0 & $-2,511$ & 0,012 \\
\hline & Pozitif sıra ${ }^{\mathrm{b}}$ & 20 & 18,70 & 374,0 & & \\
\hline & $\mathrm{Eşit}^{\mathrm{c}}$ & 22 & & & & \\
\hline \multirow[t]{3}{*}{2010} & Negatif sira ${ }^{a}$ & 6 & 18,93 & 63,5 & $-4,253$ & 0,000 \\
\hline & Pozitif sıra ${ }^{\mathrm{b}}$ & 30 & 30,18 & 602,5 & & \\
\hline & Eşit ${ }^{\mathrm{c}}$ & 17 & & & & \\
\hline \multirow[t]{3}{*}{2011} & Negatif sira ${ }^{a}$ & 16 & 16,28 & 260,5 & $-2,741$ & 0,006 \\
\hline & Pozitif sıra ${ }^{b}$ & 28 & 26,05 & 729,5 & & \\
\hline & Eşit ${ }^{c}$ & 9 & & & & \\
\hline \multirow[t]{3}{*}{2012} & Negatif sira ${ }^{a}$ & 23 & 17,48 & 402,0 & $-0,620$ & 0,535 \\
\hline & Pozitif sira ${ }^{\mathrm{b}}$ & 19 & 26,37 & 501,0 & & \\
\hline & Eşit ${ }^{\mathrm{c}}$ & 11 & & & & \\
\hline \multirow[t]{3}{*}{2013} & Negatif sira $^{a}$ & 12 & 19,54 & 234,5 & $-3,764$ & 0,000 \\
\hline & Pozitif sira ${ }^{b}$ & 37 & 26,77 & 990,5 & & \\
\hline & Eşit ${ }^{c}$ & 4 & & & & \\
\hline \multirow[t]{3}{*}{2014} & Negatif sira $^{a}$ & 18 & 18,22 & 328,0 & $-1,104$ & 0,269 \\
\hline & Pozitif sıra ${ }^{\mathrm{b}}$ & 22 & 22,36 & 492,0 & & \\
\hline & Eşit ${ }^{c}$ & 13 & & & & \\
\hline \multirow[t]{3}{*}{2015} & Negatif sıra ${ }^{a}$ & 14 & 15,04 & 210,5 & $-4,358$ & 0,000 \\
\hline & Pozitif sıra ${ }^{\mathrm{b}}$ & 38 & 30,72 & 1167,5 & & \\
\hline & Eşit ${ }^{\mathrm{c}}$ & 1 & & & & \\
\hline \multirow[t]{3}{*}{2016} & Negatif sira ${ }^{a}$ & 16 & 13,50 & 216 & $-2,947$ & 0,003 \\
\hline & Pozitif sira ${ }^{\mathrm{b}}$ & 26 & 26,42 & 687 & & \\
\hline & Eşit ${ }^{\mathrm{c}}$ & 11 & & & & \\
\hline \multirow[t]{3}{*}{2017} & Negatif sira ${ }^{a}$ & 16 & 18,56 & 297,0 & $-3,290$ & 0,001 \\
\hline & Pozitif sıra ${ }^{\mathrm{b}}$ & 34 & 28,76 & 978,0 & & \\
\hline & Eşit ${ }^{c}$ & 3 & & & & \\
\hline
\end{tabular}

ÖKK 1 : Dönem net kârının özkaynaklara oranı

ÖKK $K_{2}$ : Toplam kapsamlı gelirin özkaynaklara oranı

${ }^{\mathrm{a} O ̈ K_{K}}>\mathrm{ÖKK}_{2}$

${ }^{\mathrm{b}} \mathrm{ÖKK} \mathrm{K}_{1}<\mathrm{ÖKK}_{2}$

${ }^{c} \mathrm{O} K_{1}=\ddot{O} K_{2}$

Son olarak, toplam kapsamlı gelirin dönem kârından yüksek çıkmasında etkili olan diğer kapsamlı gelir unsurlarının istatistiki olarak tespiti amacı ile çapraz tablo analizi gerçekleştirilmiş ve analiz sonuçları Tablo 10'da sunulmuştur. Analiz sonuçları diğer kapsamlı gelir unsurlarından maddi ve maddi olmayan duran varlıkların yeniden değerleme farkları (Ki-kare=6.145, p<0,05) ve kur değişim farkları (Ki-kare=3,762, p<0,10) kalemlerinin toplam kapsamlı gelirin dönem kârından daha yüksek çıkmasında istatistiki olarak etkili olduklarını göstermiştir. Bu bulgular doğrultusunda yeniden de ğerleme ve kur değişim farkları kalemlerinin işletmelerin toplam kapsaml gelirlerinin dönem kârlarından daha yüksek çıkmasında etkili olan diğer kapsamlı gelir unsurları oldukları sonucu elde edilmiştir. Ayrıca, 2012 ve 2014 yıllarında toplam kapsamlı gelir ile dönem kârı arasında istatistiki olarak anlamlı bir fark bulunamamasının sebebi de yeniden de ğerleme ve kur değişim farkları kalemlerinin bu yıllarda diğer yıllara oranla daha düşük tutarlarda gerçekleşmeleri olabilir.

Tablo 10. Toplam kapsamlı gelirin dönem kârından yüksek olmasında etkili olan diğer kapsamlı gelir unsurları

\begin{tabular}{|c|c|c|c|c|}
\hline $\begin{array}{l}\text { Diğer kapsamll gelir } \\
\text { unsurlart }\end{array}$ & & & $T K G>D K$ & $T K G<D K$ \\
\hline \multirow{3}{*}{$\begin{array}{l}\text { Yeniden değerleme } \\
\text { farkları }\end{array}$} & Var & $\mathrm{N}$ & 103 & 43 \\
\hline & Yok & $\mathrm{N}$ & 194 & 137 \\
\hline & & plam & 297 & 180 \\
\hline \multicolumn{5}{|c|}{ Ki-kare değeri: 6,145 Anlamlılık düzeyi (p): 0,014 } \\
\hline \multirow{3}{*}{$\begin{array}{l}\text { Aktüeryal kazanç ve } \\
\text { kayıplar }\end{array}$} & Var & $\mathrm{N}$ & 155 & 100 \\
\hline & Yok & $\mathrm{N}$ & 142 & 80 \\
\hline & & plam & 297 & 180 \\
\hline \multicolumn{5}{|c|}{ Ki-kare değeri: 0,511 Anlamlılık düzeyi (p): 0,508 } \\
\hline \multirow{3}{*}{ Kur değişim farkları } & Var & $\mathrm{N}$ & 227 & 123 \\
\hline & Yok & $\mathrm{N}$ & 70 & 57 \\
\hline & \multicolumn{2}{|c|}{ Toplam } & 297 & 180 \\
\hline
\end{tabular}


K1lıç, M. / Journal of Yasar University, 2019, 14/54, 127-140

\begin{tabular}{|c|c|c|c|}
\hline \multicolumn{4}{|c|}{ Ki-kare değeri: 3,762 Anlamlılık düzeyi (p): 0,055 } \\
\hline Finansal araçların & Var & 124 & 67 \\
\hline değerleme farkları & Yok & 173 & 113 \\
\hline \multicolumn{4}{|c|}{ Toplam 297} \\
\hline \multicolumn{4}{|c|}{ Ki-kare değeri: 0,957 Anlamlılık düzeyi (p): 0,337 } \\
\hline Nakit akış riskine ilişkin & Var & 102 & 59 \\
\hline kazanç ve kayıplar & Yok & 195 & 121 \\
\hline & Toplam & 297 & 180 \\
\hline \multicolumn{4}{|c|}{ Ki-kare değeri: 0,123 Anlamlılık düzeyi (p): 0,762 } \\
\hline
\end{tabular}

\section{Sonuç}

Türkiye'deki vergi muhasebesi uygulamalarında, ihtiyatlılık kavramı gereğince gerçekleşmemiş kayıplar dönemin gelir tablosunda tahakkuk ettirilirken gerçekleşmemiş gelirler tahakkuk ettirilmemektedir (Gücenme Gençoğlu vd., 2014). Diğer kapsamlı gelir unsurları, özkaynaklarda artış veya azalışa neden olmakta ancak henüz gelir ve gider tanımlarına uymadıkları için normal gelirler ve giderler arasında gösterilmemektedirler. UMS 1 standardında yapılan değişiklik sonrasında işletmeler özkaynaklarda raporladıkları gerçekleşmemiş gelir ve giderleri gelir tablosuna ekleyerek kapsamlı gelir tablosunda sunmaya başlamışlardır. Kapsamlı gelir tablosu, geleneksel kâr (zarar) tutarlarının yanı sıra diğer kapsamlı gelir unsurlarını içeren ve finansal tablo kullanıcılara bu doğrultuda bilgi sunan bir tablo olarak ortaya çıkmıştır.

$\mathrm{Bu}$ çalışmada, BİST’te işlem gören işletmelerin kapsamlı gelir tabloları incelenmiştir ve diğer kapsamlı gelir unsurlarını raporlama düzeyleri tespit edilmiştir. Bu amaçla, 53 adet işletmenin 2009 ve 2017 yılları arasındaki kapsamlı gelir tabloları incelenmiştir. Çalışmanın sonuçlarına göre, diğer kapsamlı gelir unsurlarını sunan işletme sayısı önemli bir düzeyde artış göstermiştir. 2009 ve 2012 yılları arasında kapsamlı gelir bilgisini tek tablo ve iki tablo formatında sunan işletme sayısı birbirine eşit iken, sonraki yıllarda iki tablo formatını tercih eden işletme sayısında önemli bir artış gerçekleşmiştir.

İşletmelerin en çok raporladıkları diğer kapsamlı gelir unsuru kur değişim farkları olarak tespit edilmiştir. 2009 ve 2017 yılları arasında raporlanma oranında en fazla artış olan diğer kapsamlı gelir unsurunun ise aktüeryal kazanç ve kayıplar olduğu gözlenmiştir. Ayrıca, çalışma kapsamında diğer kapsamlı gelir unsurlarının toplam kapsamlı gelir ve kârlılık oranlarına etkisi istatistiki olarak analiz edilmiştir. Analiz sonuçları 2012 ve 2014 yılları dışında diğer kapsamlı gelir unsurları hem toplam kapsamlı geliri hem de özkaynak kârlılık oranlarını istatistiki olarak anlamlı ve pozitif bir şekilde etkilediğini göstermiştir. Çalışmada toplam kapsamlı gelirin dönem kârından yüksek çıkmasında etkili olan diğer kapsamlı gelir unsurları incelenmiş ve yeniden değerleme ve kur değişim farkları kalemlerinin işletmelerin toplam kapsamlı gelirlerinin dönem kârlarından daha yüksek çıkmasında etkili olan diğer kapsamlı gelir unsurları oldukları tespit edilmiştir.

Diğer kapsamlı gelir kalemlerinin hem toplam kapsamlı geliri hem de kârlılık oranlarını istatistiki olarak anlamlı ve pozitif bir şekilde etkiliyor olması, finansal tablo kullanıcılarının işletme performanslarını değerlendirirken bu kalemleri de göz önünde bulundurmasının önemine işaret etmektedir. Kapsamlı gelir tablosu, kapsamlı gelir kavramının yaygınlaşmış ile birlikte gittikçe önem kazanan bir finansal performans değerleme aracı olmuştur. IASB'nin diğer kapsamlı gelir unsurlarının raporlanmasına ve geleneksel gelir tablosuna ek olarak ayrı bir tabloda sunulmasına önem vermesi, kapsamlı gelire performans değerleme açısından verdiği önemin bir göstergesi olarak yorumlanmaktadır. Geleneksel dönem kârı büyük oranda işletme yönetiminin kontrolünde olan faktörleri içermektedir. Diğer kapsamlı gelir unsurları ise faiz oranları, türev araçları ve döviz kurları gibi işletme yönetiminin kontrolünde olmayan faktörleri de içermektedir (Gazzola ve Amelio, 2014). Finansal tablo kullanıcılarının işletmenin kontrolünde olmayan riskleri de içeren kapsamlı geliri performans değerlemesi yaparken göz önünde bulundurmaları daha doğru kararlar almalarını sağlayacaktır. Ayrıca, kapsamlı gelir kalemlerinin açıklanması finansal bilgilerin niteliğini artırmakta ve finansal tablo kullanıcılarının işletme faaliyetlerinin sonuçlarını bir bütün olarak görebilmelerini sağlamaktadır.

Diğer kapsamlı gelir unsurlarının geleneksel dönem kârına eklenmesi eleştiri konusu olmaktadır. Kapsamlı gelir tablosu, diğer kapsamlı gelir unsurlarının ayrıca izlenmelerini ve gösterimlerini sağlamaktadır. Özellikle, iki tablo formatında geleneksel gelir tablosuna ek olarak sunulan diğer kapsamlı gelir unsurları olası tutar karışıklıklarını engelleyecektir. Bu doğrultuda, işletmelerin tek tablo formatı yerine iki tablo formatını tercih etmeleri önerilebilir. Bu çalışmanın sonuçlarına göre 2013 yılından itibaren iki tablo formatını tercih eden işletme sayısında önemli miktarda bir artış gerçekleşmiştir. Bu artışın devam etmesi finansal raporlama adına olumlu bir bulgu olarak değerlendirilebilir.

$\mathrm{Bu}$ çalışma, çeşitli yönleriyle alandaki yazına katkı sunacaktır. Öncelikle, işletmelerin kapsamlı gelir bilgi raporlama uygulamalarını dokuz yıllık bir süreç için inceleyen Türkiye'deki ilk araştırmadır. Ayrıca, diğer kapsamlı gelir unsurlarının kârlılık oranları üzerindeki etkisini istatistiki olarak inceleyen de ilk çalışmadır.

Çalışma, gelecekteki araştırmalar için yol gösterici olacaktır. İlk olarak, kapsamlı gelir bilgisinin finansal tablo kullanıcılar açısından nasıl değerlendirildiği anket veya mülakat teknikleriyle araştırılabilir. Ayrıca, kapsamlı gelirin işletme performansı, firma değeri ve nakit akışları tahmini ile olan ilişkisi sonraki araştırmalarda incelenebilir. Bunun yanı sıra, gelecekteki araştırmalarda kapsamlı gelir sunumunda sektörel farklılıklar analiz edilebilir. 


\section{KAYNAKÇA}

Acar, Vedat. 2013. "TMS 1: Finansal Tabloların Sunuluşu Standardı Kapsamında Hizmet Sektöründe Çeşit Esasına Göre Düzenlenebilecek Gelir Tablosunun İçerik ve Şekil Yönünden İncelenmesi." Muhasebe ve Vergi Uygulamaları Dergisi, 6(3): 15-41.

Bayri, Osman. 2010. "Tekdüzen Muhasebe Sistemine ve Türkiye Muhasebe-Finansal Raporlama Standartlarına Göre Gelir Tablolarının Biçimsel Yapısı, Kapsamı ve İçeriğinin Karşılaştırmalı Analizi." Muhasebe ve Finansman Dergisi, 47: 95-110.

Bhamornsiri, Sak ve Casper Wiggins. 2001. "Comprehensive Income Disclosures." The CPA Journal, 71(10): 54-56.

Cahan, Steven F., Courtenay, Stephen M., Gronnewoller, Paul L. ve Upton, David R. 2000. "Value Relevance of Mandated Comprehensive Income Disclosures." Journal of Business Finance and Accounting, 27(9-10): 12331265 .

Chambers, Dennis, Linsmeier, Thomas J., Shakespeare, Catherine ve Sougiannis, Theodore. 2007. "An Evaluation of SFAS No. 130 Comprehensive Income Disclosures." Review of Accounting Studies, 12(4): 557-593.

Çetinoğlu, Tansel ve Tutkavul, Kadir. 2013. "Aracı Kurumlarda Kapsamlı Gelirin Raporlanması ve Faaliyet Sonuçlarına Etkisinin İncelenmesi." Dumlupınar Üniversitesi Sosyal Bilimler Dergisi, 38: 143-169.

Dastgir, Mohsen ve Velashani, Ali Saeedi. 2008. "Comprehensive Income and Net Income as Measures of Firm Performance: Some Evidence for Scale Effect." European Journal of Economics, Finance and Administrative Sciences, 12(12): 123-133.

De Cristofaro, Tiziana ve Falzago, Barbara. 2014. "What Trend for Comprehensive Income Presentation? Evidence from Italy." International Journal of Accounting and Taxation, 2(3): 17-40.

Demir, Volkan, Bahadır, Oğuzhan ve Öncel, Aslı Gül. 2013. "What is the Best Measure of Financial Performance? Comprehensive Income versus Net Income: Evidence from Turkey." İktisat Isşletme ve Finans, 28(323): 73-96.

Doğan, Mustafa ve Ertugay, Emrah. 2010. "Türkiye Finansal Raporlama Standartlarına Göre Kapsamlı Gelir Tablosu ve Örnek Uygulama." Muhasebe ve Vergi Uygulamalarl Dergisi, 3: 117-138.

Durgut, Mehmet ve Kaya, Uğur. 2013. "TMS 19 Çalışanlara Sağlanan Faydalar Standardının IMKB'deki Şirketlerde Uygulama Düzeyinin Değerlendirilmesi." Atatürk Üniversitesi İktisadi ve İdari Bilimler Dergisi, 27(2): 179205.

Financial Accounting Standards Board (FASB). 1985. "Statement of Financial Accounting Concepts No. 6: Elements of Financial Statements." http://www.fasb.org/resources/ccurl/792/293/CON6.pdf (03.04.2016).

Fernández, Francisco Sousa ve Arana, María Mercedes Carro. 2010. "Effects of Comprehensive Income on ROE in a Context of Crisis: Empirical Evidence for IBEX-35 Listed Companies." International Business \& Economics Research Journal, 9(1): 117-128.

Ferraro, Olga. 2011. "Comprehensive Income in Italy: Reporting Preferences and Its Effects on Performance Indicators." Journal of Modern Accounting and Auditing, 7(12): 1315-1328.

Frendzel, Maciej ve Szychta, Anna. 2013. "Comprehensive Income Reporting: Empirical Evidence from the Warsaw Stock Exchange.", Social Sciences, 82(4): 7-16.

Gazzola, Patrizia ve Amelio, Stefano. 2014. "The Impact of Comprehensive Income on the Financial Ratios in a Period of Crises", Procedia Economics and Finance, 12: 174-183.

Gökgöz, Ahmet. 2013. "Diğer Kapsamlı Gelirler ve Muhasebeleştirilmesi." Muhasebe ve Finansman Dergisi, $57: 23-$ 38.

Gücenme Gençoğlu, Ümit, Poroy Arsoy, Aylin, Ertan, Yasemin ve Bora, Tuba. 2014. "TMS/TFRS’ye Dönüştürülen Finansal Tabloların Denetim Modelinin Özellikleri." Muhasebe ve Finansman Dergisi, 64: 1-26.

Gürkan, Serhan ve Köse, Yasemin. 2013. "Diğer Kapsamlı Gelir Kalemleri ile İşletmenin Piyasa Değeri Arasındaki İlişki." Uluslararası Işsletme ve Yönetim Dergisi, 1(3): 269-280.

Köse, Yasemin ve Gürkan, Serhan. 2014. "Diğer Kapsamlı Gelir ile Piyasa Değeri Arasındaki İlişki: Borsa İstanbul'da İşlem Gören Şirketlerde Bir Araştırma." Muhasebe Bilim Dünyası Dergisi, 16(1): 21-44.

Haftac1, Vasfi ve Pehlivanl, Davut. 2007. "UMS 39 ve Uygulamada Karşılaş1lan Sorunlar." Kocaeli Üniversitesi Sosyal Bilimler Enstitü Dergisi, 13(1): 139-151.

Kamu Gözetimi Kurumu (KGK). 2018. "TMS 1 Finansal Tabloların Sunuluşu." http://www.kgk.gov.tr/Portalv2Uploads/files/Duyurular/v2/TMS/TMS\%201\%20Finansal\%20Tablolar\%C4\%B $1 \mathrm{n} \% 20$ Sunulu\%C5\%9Fu.pdf (01.01.2019).

Kanagaretnam, Kiridaran, Mathieu, Robert ve Shehata, Mohamed. 2009. "Usefulness of Comprehensive Income Reporting in Canada." Journal of Accounting Public Policy, 28(4): 349-365.

Kaplanoğlu, Emre. 2014. "TMS-TFRS Çerçevesinde Diğer Kapsamlı Gelirler ve Muhasebe Uygulamaları." Muhasebe ve Finansman Dergisi, 63: 75-92.

Kaval, Hasan. 2011. "TMS Kapsamında Çeşit Esasına Göre Kâr Zarar ve Diğer Kapsamlı Gelirler Tablosu." EYaklaşım, 1-28.

Kreuze, Jerry G. ve Newell, Gale E. 1999. "The Relationship of Net Income to Comprehensive Income: An Analysis of Fortune 500 Companies." Mid-American Journal of Business, 14(1): 53-58.

Kubota, Keiichi, Suda, Kazuyuki ve Takehara, Hitoshi. 2011. "Information Content of Other Comprehensive Income and Net Income: Evidence for Japanese Firms." Asia-Pacific Journal of Accounting \& Economics, 18(2): 145168. 
Küçük, Emre. 2015. "Diğer Kapsamlı Kâr/Zarar Tablosu Hesaplarının Ertelenmiş Vergi Etkisi: Özellikli Durumların Değerlendirilmesi." Dokuz Eylül Üniversitesi İktisadi ve İdari Bilimler Dergisi, 30(1): 167-201.

Marchini, Pier Luigi ve D'este, Carlotta. 2015. "Comprehensive Income and Financial Performance Ratios: Which Potential Effects on RoE and on Firm's Performance Evaluation?." Procedia Economics and Finance, 32: 1724-1739.

Ngmenipuo, Iddrisu Mohammed ve Issah, Osman. 2014. "Reporting Comprehensive Income Issues Empirical Evidence from Ghana." International Journal of Economics, Commerce and Management, 2(12): 1-22.

Ngmenipuo, Iddrisu Mohammed ve Issah, Osman. 2015. "The Impact of Comprehensive Income Reporting on Financial Performance of Ghanaian Firms with Public Accountability." International Journal of Economics, Commerce and Management, 3(3): 1-12.

Örten, Remzi, Kaval, Hasan ve Karapınar, Aydın. 2015. Türkiye Muhasebe-Finansal Raporlama Standartları (TMSTFRS). 9. Bask1. Ankara: Gazi Kitabevi.

Öztürk, Can. 2009. "2007 Yılında UMS 1: Muhasebesel Değişiklikler ve Yorumlar." Muhasebe Bilim Dünyası Dergisi, 11(2): 87-106.

Pamukçu, Fatma. 2011. "Gerçeğe Uygun Değer Muhasebesi ve Finansal Tablolara Etkisi." Mali Çözüm Dergisi, 103: 79-95.

Păşcan, Irina-Doina. 2014. "Does Comprehensive Income Tell Us More about an Entity’s Performance Compared to Net Income? Study on Romanian Listed Entities." Procedia Economics and Finance, 15: 1077-1082.

Sarığlu, Kerem ve Türel, Aslı. 2012. "Türkiye Finansal Raporlama Standartlarına Göre Kapsamlı Gelir (Kâr) Tablosu: Kullanılan Dil Üzerine Eleştiri ve Sunum Şekli Tercihleri Üzerine Bir Araştırma." Vergi Sorunları Dergisi, 290: 82-94.

Schaberl, Philipp D. ve Victoravich, Lisa M. 2015. "Reporting Location and the Value Relevance of Accounting Information: The Case of Other Comprehensive Income." Advances in Accounting, incorporating Advances in International Accounting, 31(2): 239-246.

Ulusan, Hikmet. 2013. "Kapsamlı Kâr (Zarar): Raporlama Yöntemi Tercihleri ve Finansal Performansın Raporlanmasına Etkisi üzerine bir Araştırma." Cumhuriyet Üniversitesi İktisadi ve İdari Bilimler Dergisi, 14(2): 45-72.

Zeytinoğlu, Emin, Şentürk, Fatih ve Elitaş, Cemal. 2015. "Çalışanlara Sağlanan Faydalar Standardı ve Kıdem Tazminatının Türkiye'deki Mevcut Düzenlemeler Kapsamında İncelenmesi." Muhasebe Bilim Dünyası Dergisi, 17(4): 737-758. 